\title{
Risk factors for developing acute gastrointestinal, skin or respiratory infections following obstacle and mud run participation, the Netherlands, 2017
}

Elisabeth M den Boogert ${ }^{1}$, Danielle M Oorsprong ${ }^{1}$, Ewout B Fanoy ${ }^{2,3}$, Alexander CAP Leenders ${ }^{4}$, Alma Tostmann ${ }^{5}$, Adriana SG van

Dam ${ }^{1}$

1. Department of Infectious Disease Control, Municipal Health Service Hart voor Brabant, 's-Hertogenbosch, the Netherlands

2. Department of Infectious Disease Control, Public Health Service Rotterdam-Rijnmond, Rotterdam, the Netherlands

3. Centre for Infectious Diseases, Epidemiology and Surveillance, National Institute for Public Health and the Environment (RIVM), Bilthoven, the Netherlands

4. Department of Medical Microbiology and Infection Control, Jeroen Bosch Hospital, 's-Hertogenbosch, the Netherlands

5. Academic Public Health Initiative AMPHI, Department of Primary and Community Care, Radboud Centre for Infectious Diseases, Nijmegen, the Netherlands

Correspondence: Elisabeth M. den Boogert (e.den.boogert@ggdhvb.nl)

Citation style for this article:

den Boogert Elisabeth M, Oorsprong Danielle M, Fanoy Ewout B, Leenders Alexander CAP, Tostmann Alma, van Dam Adriana SG. Risk factors for developing acute gastrointestinal, skin or respiratory infections following obstacle and mud run participation, the Netherlands, 2017. Euro Surveill. 2019;24(40):pii=1900088.

https://doi.org/10.2807/1560-7917.ES.2019.24.40.1900088

Article submitted on 25 Jan 2019 / accepted on 13 Jun 2019 / published on 03 Oct 2019

Background: In the Netherlands, obstacle, mud and survival runs are increasingly popular. Although outbreaks of gastroenteritis have been reported following these events, associated health risks have not been systematically assessed. Aim: To investigate the incidence of acute gastrointestinal infections (AGI), skin infections (SI) and respiratory infections (RI) among obstacle run participants, as well as risk factors. Methods: Between April and October 2017, we conducted a retrospective cohort study among 2,900 participants of 17 obstacle runs in the Netherlands. Demographic, symptomatic and behavioural data were collected from participants via an online questionnaire 1 week after participation in an obstacle run. Stool specimens were obtained from respondents for microbiological tests. Adjusted relative risks (aRR) and 95\% confidence intervals (CI) using multilevel binomial regression analysis were calculated. Results: Of 2,646 respondents (median age: 33 years; $53 \%$ male), 76 had AGI after the obstacle run; ingesting mud was associated with AGI (aRR: 1.7; 95\% Cl: 1.2-4.9) and 38 respondents had AGI during or in the week before the obstacle run. Overall, 103 respondents reported $\mathrm{SI}$ and $163 \mathrm{RI}$. Rinsing off in a hot tub was associated with SI (aRR: 2.2; 95\% Cl: 1.7-2.8). Of 111 stool specimens, 13 tested positive for six different pathogens. No clusters were found. Conclusion: The reported incidence of AGI, SI and RI was low. Risk of these infections could be decreased by informing participants on preventive measures, e.g. showering vs rinsing in the hot tub, avoiding ingesting mud and not participating with symptoms of AGI.

\section{Introduction}

In the Netherlands, obstacle, mud and survival runs (for the purposes of this paper, collectively referred to as 'obstacle runs') are increasingly popular. Initially, trained or professional runners were the main participants in these races, but the sport has developed into a fun activity for friends and families. There is a growing number of participants each year (13,000 in 2012 to $>250,000$ in 2017 [1]). The minimum age for participation varies between obstacle runs; it is usually based on the run's distance and can be as young as 5 years old [2]. In 2017, over 150 obstacle runs were organised in the Netherlands [3]. Obstacle runs are races in which participants encounter different manufactured obstacles while running around a predefined course [4]. A mud run is basically the same, but intentionally features more mud [4]. Survival runs are a combination of an obstacle run and an endurance event; these require more technique and training than obstacle runs and are often non-commercial compared to obstacle races and mud runs $[5,6]$.

As participants of obstacle runs are required to run, crawl or swim through untreated water and mud, risk of injury and infectious diseases such as acute gastrointestinal infection (AGI), respiratory infection (RI) and skin infection $(\mathrm{SI})$ can be more prevalent in these races compared to more conventional running races. Since 2010, there have been multiple reports of AGI outbreaks following obstacle runs, open water swimming events and mountain biking events, and the ingestion of mud or water during these races was associated with the infections [7-14]. In Belgium and the Netherlands, 


\section{Box}

Case definitions for acute gastrointestinal, respiratory and skin infections, the Netherlands, 2017

AGI was defined as the development of any diarrhoea and/or vomiting within 14 days after the run.

SI was defined as the development of red bumps on the skin or other skin abnormalities within 14 days after the run.

RI was defined as the development of a cold, sore throat or cough within 14 days after the run.

Injuries were defined as muscle or joint injuries contracted during the run.

Wound was defined as a wound (cut or abrasion) contracted during the run.

AGI: acute gastrointestinal infection; RI: respiratory infection; SI: skin infection.

several cases of leptospirosis were reported in 2015 after participation in an obstacle run and in the Netherlands, one case of tularaemia was linked to an obstacle run [15-17]. However, these reports do not provide information on the infectious disease risks and potential risk factors associated with obstacle run participation in general.

Although there are publications about outbreaks following obstacle runs, a more systematic approach to identify the events' potential risk factors is lacking. Research on the potential health risks of obstacle runs is therefore warranted, and outcomes could potentially support recommendations that may help to further improve safety and preventive measures at these events.

This study investigated potential risk factors for developing AGI, RI or SI-such as accidentally swallowing mud/water, time between finish and rinsing off, or type of clothes worn-following participation in obstacle runs in the Netherlands. With the results, we aim to develop evidence-based preventative recommendations for organisers and participants of obstacle runs.

\section{Methods}

\section{Study design}

A retrospective cohort study was performed in four of 12 provinces in the Netherlands (Zuid-Holland, NoordBrabant, Limburg and Gelderland) among participants of 17 obstacle runs that took place between April and October 2017. Obstacle runs were selected based on small $(n<1,000)$ and large $(n>1,000)$ numbers of participants to include both professional and voluntary organisations.

\section{Study population}

The study population was defined as all participants that took part in at least one of the 17 selected obstacle runs. Organisers of each obstacle run were contacted before the race and given information on the study. They were asked to send a message to all participants. The message contained a link to an online questionnaire and was sent via email or posted to social media or the obstacle run's website 7-10 days after the event. For organisers, sending the message to participants was considered consent for participation in the study; for participants, starting the questionnaire was considered giving consent.

\section{Case definitions}

Case definitions were based on guidelines from the National Coordination for Communicable Diseases Control in the Netherlands $[18,19]$ and were defined by a medical doctor and an infectious disease epidemiologist.

\section{Data collection}

\section{Epidemiological}

Questionnaire data were collected via Collector innovative surveys [20]. The questionnaire included questions related to: (i) demographic characteristics; (ii) run-specific information including distance, time started and duration; (iii) health complaints experienced before, during and after the obstacle run, e.g. vomiting, diarrhoea, headache, injuries and wounds; and (iv) potential risk factors for infectious diseases, e.g. swallowing water/mud, type of clothing worn, food and drinks consumed, time between completion of the obstacle run and showering, chronic diseases (e.g. hay fever or other self-defined allergies, diabetes, immune disorders) and medications taken (e.g. antacids, antibiotics). Organisers could also add their own questions to get feedback regarding the organisation of the obstacle run.

Participants had ca 1 week to complete the questionnaire. Organisers of 12 of the obstacle runs also sent a reminder email 3-8 days after the first invitation or posted a reminder on social media. An example of the questionnaire can be seen in Supplement $\mathrm{S}_{1}$.

\section{Microbiological}

Respondents with known contact details who indicated that they had symptoms of AGI before, during or after the run were asked if they would be willing to collect a stool specimen and send it to Jeroen Bosch Hospital's microbiological laboratory for analysis. If they accepted, a stool sample taking kit was sent to their home address. Where possible, 10 respondents reporting $\mathrm{AGI}$ symptoms per obstacle run were included for stool testing within 3 weeks after the run; if less than 10 respondents reported symptoms of $A G I$, respondents who did not report symptoms of AGI were invited to provide a stool sample. This decision was made on the basis that an asymptomatic individual 
TABLE 1

Characteristics of respondents from 17 obstacle runs, the Netherlands, $2017(\mathrm{n}=2,900)$

\begin{tabular}{|c|c|c|}
\hline Characteristics & $n$ & $\%$ \\
\hline Sex & 2,693 & 100 \\
\hline Male & 1,435 & 53.3 \\
\hline Female & 1,258 & 46.7 \\
\hline Missing & 207 & NA \\
\hline Age (years) & 2,692 & 100 \\
\hline$<18$ & 311 & 11.6 \\
\hline $19-25$ & 363 & 13.5 \\
\hline $26-35$ & 863 & 32.1 \\
\hline $36-45$ & 784 & 29.1 \\
\hline$>45$ & 371 & 13.8 \\
\hline Missing & 208 & NA \\
\hline \multicolumn{3}{|l|}{ Self-reported symptoms } \\
\hline Acute gastrointestinal infections & 2,808 & 100 \\
\hline Yes & 76 & 2.7 \\
\hline No & 2,732 & 97.3 \\
\hline Missing & 92 & NA \\
\hline Skin infections & 2,790 & 100 \\
\hline Yes & 103 & 3.7 \\
\hline No & 2,687 & 96.3 \\
\hline Missing & 110 & NA \\
\hline Respiratory infections & 2,790 & 100 \\
\hline Yes & 163 & 5.8 \\
\hline No & 2,627 & 94.2 \\
\hline Missing & 110 & NA \\
\hline Current smoker & 2,691 & 100 \\
\hline Yes & 185 & 6.9 \\
\hline No & 2,506 & 93.1 \\
\hline Missing & 209 & NA \\
\hline Use of medication ${ }^{a}$ & 2,658 & 100 \\
\hline Yes & 216 & 8.1 \\
\hline No & 2,442 & 91.9 \\
\hline Missing & 242 & NA \\
\hline Allergies $^{\mathrm{b}}$ & 2,658 & 100 \\
\hline Yes & 449 & 16.9 \\
\hline No & 2,209 & 83.1 \\
\hline Missing & 242 & $\mathrm{NA}$ \\
\hline Other chronic diseases ${ }^{c}$ & 2,658 & 100 \\
\hline Yes & 411 & 15.5 \\
\hline No & 2,247 & 84.5 \\
\hline Missing & 242 & NA \\
\hline $\begin{array}{l}\text { Exposure to open water or obstacle run (past } 3 \\
\text { months) }\end{array}$ & 2,864 & 100 \\
\hline Yes & 1,080 & 37.7 \\
\hline No & 1,784 & 62.3 \\
\hline Missing & 36 & NA \\
\hline
\end{tabular}

NA: not applicable.

a For example, antibiotics or antacids.

${ }^{b}$ For example, hay fever or other self-defined allergies.

' Other than allergies; for example, diabetes, immune disorders or gastrointestinal diseases.

Additional information on the questions asked in the questionnaire can be found in Supplement S1. $_{1}$ infected with a pathogen could still be a potential risk for onward transmission.

Stool specimens were tested for Salmonella species, Shigella spp., Campylobacter spp., Shigatoxin producing Escherichia coli (STEC), noro- and sapovirus, Entamoeba histolytitica, Cryptosporidium parvum/hominis and Giardia lamblia, all by reverse transcriptase-PCR (RT-PCR). Specimens were also tested for rota- and adenovirus infections with a qualitative immunochromatographic test. STEC-positive specimens were further tested by RT-PCR to determine whether the strain belonged to the subgroup of enterohaemorrhagic Escherichia coli (EHEC).

\section{Environmental}

A checklist was developed to identify potential environmental health hazards at an obstacle run. During each of the 17 obstacle runs we visually inspected the trails for animal faeces and asked the organisers whether the water had been officially approved by local authorities for swimming, according to the items provided on the checklist. We assessed the hygienic standards of facilities-e.g. toilets, showers and food trucks-in the event area and also took water samples at two or three random points along the runs. These were collected so that samples would be rapidly available for analysis in the case of an outbreak. They were not collected for comparison between obstacle runs and were stored following collection.

\section{Outbreak definition}

An outbreak was defined as multiple participants of an obstacle run reporting the same clinical symptoms following participation and/or submitting stool specimens that tested positive for the same pathogen. The definition of an outbreak also depended on the specific pathogen found or the health complaints reported; these parameters were not specified beforehand for all possible infectious diseases. In general, we defined an outbreak as a higher incidence of an infectious disease in the study cohort than the expected incidence in the general Dutch population at the same time. This was assessed by a medical doctor with experience working in the field of infectious disease control.

\section{Data analysis}

The primary outcome of this study was the association between potential risk factors during obstacle runs, demographics and the development of AGI, RI and SI. Attack rates were calculated for subgroups of exposure. To determine the association between different potential risk factors and development of infections, a univariable multilevel analysis was conducted. Multilevel analysis was performed to take into account the potential clustering of effects among the 17 runs and relative risks (RR) were calculated accordingly. Following the univariable analysis, we included factors associated with infection with a $p$ value $<0.05$ in univariable analysis in a multivariable multilevel binomial regression. We considered a $p$ value of $<0.05$ to 
TABLE 2

Characteristics of the obstacle runs, the Netherlands, 2017 $(\mathrm{n}=17)$

\begin{tabular}{|c|c|}
\hline Characteristics & n \\
\hline \multicolumn{2}{|l|}{ Number of participants } \\
\hline$<1,000$ & 9 \\
\hline$\geq 1,000$ & 8 \\
\hline \multicolumn{2}{|l|}{ Event duration (days) } \\
\hline 1 & 10 \\
\hline 2 & 7 \\
\hline \multicolumn{2}{|l|}{ Weather conditions } \\
\hline Heavy rain & 0 \\
\hline Light rain & 4 \\
\hline No rain & 13 \\
\hline \multicolumn{2}{|l|}{ Temperature $\left({ }^{\circ} \mathrm{C}\right)$} \\
\hline$<15.0$ & 0 \\
\hline $15.1-20.0$ & 7 \\
\hline $20.1-25.0$ & 6 \\
\hline$>25.1$ & 4 \\
\hline \multicolumn{2}{|l|}{ Swimming water } \\
\hline Only official & 2 \\
\hline Only non-official & 12 \\
\hline Both official and non-official ${ }^{a}$ & 3 \\
\hline \multicolumn{2}{|l|}{ Hygiene facilities } \\
\hline Running water & 11 \\
\hline Paper towels & 4 \\
\hline Soap & 4 \\
\hline Rinse facilities $^{b}$ & 16 \\
\hline \multicolumn{2}{|c|}{ Food and water distributed during obstacle run } \\
\hline Food & 14 \\
\hline Fruit without peel ${ }^{c}$ & 6 \\
\hline Free drinking water & 17 \\
\hline Animal faeces present on trail & 7 \\
\hline
\end{tabular}

a Official swimming water was officially approved for swimming by local authorities and non-official swimming water was not checked by local authorities.

${ }^{b}$ For example, shower, garden hose or cold water tub.

c In 13 obstacle runs.

${ }^{d}$ Depending on the obstacle run this was either bottled water or tap water.

Additional information on the questions asked in the questionnaire can be found in Supplement S1.

be statistically significant. Data were analysed using SPSS statistics 21 (IBM, New York, United States (US)) and STATA 14 (StataCorp, College Station, Texas, US).

\section{Results}

In total, 17 obstacle runs carried out over 14 weekends (between April and October 2017) in the Netherlands were included in this study. Of these runs, 12 were in the provinces of Noord-Brabant, two in Zuid-Holland, two in Gelderland and one in Limburg. The runs had ca 30,000 participants in total, ranging from $230-7,600$ per run.

\section{Questionnaire response}

Of the 30,000 participants, 2,900 started the questionnaire and 2,646 (91\%) completed it. Distribution of the questionnaire was not consistent between the obstacle runs, as contact information (specifically email addresses) was not available for all participants, e.g. when one participant signed up on behalf of a group. Therefore, for nine obstacle runs the link to the questionnaire was posted on social media or the obstacle run's website. Because of this, it was not possible to determine precisely how many participants were reached via email, social media or the website in order to calculate the response rate.

\section{Characteristics of the study population}

The median age was 33 years (range: $5-71$ years) and 1,435 (53\%) were male. Following an obstacle run, $2.7 \%$ of respondents reported $\mathrm{AGI}, 3.7 \%$ reported $\mathrm{SI}$ and $5.8 \%$ reported $\mathrm{RI}$ (Table 1 ). The majority of respondents reported that they had no allergies or other chronic diseases $(83.1 \%$ and $84.5 \%$, respectively). A small number of respondents $(8.1 \%)$ used medication at the time of the run.

\section{Characteristics of the obstacle runs}

Table 2 describes the main characteristics assessed using the environmental checklist. Of 17 obstacle runs, 10 were single-day events, 13 took place on a day with no rain, 11 had running water for handwashing (but most did not have paper towels and soap), 16 had facilities for participants to rinse off afterwards and 14 handed out free food. At one obstacle run, fruit and packaged foods (i.e. granola bars) were distributed. At another, energy bars were handed out, but not fruit. Of the 13 obstacle runs where fruit was handed out, at six runs, volunteers peeled the fruit before distributing it to participants. Environmental samples were not tested, because there was no reported outbreak nor did respondents of the same run test positive for the same pathogen.

\section{Epidemiological determinants}

Reported health complaints

In total, 641 of 2,813 (22.8\%) respondents reported health complaints (e.g. headache, stomach ache and vomiting) following participation in an obstacle run. Of those, five discovered a tick during or after the run, 156 (5.6\%) reported receiving a wound, 131 (4.7\%) reported an injury (mostly concerning the knee $(n=45)$ and ankle $(n=25)$ ), two respondents broke a bone and six tore a muscle.

In all three main health complaints reported, (AGI, RI and $\mathrm{SI}$ ) females were more likely to report infections than males; AGI: 47 (68\%) vs 22 (32\%); SI: 68 (69\%) vs 31 (31\%); RI: 103 (69\%) vs 47 (31\%). 


\section{TABLE 3A}

Determinants for developing acute gastrointestinal infections in obstacle run participants, the Netherlands, $2017(\mathrm{n}=2,808)$

\begin{tabular}{|c|c|c|c|c|c|c|c|}
\hline \multirow[b]{2}{*}{ Variables } & \multirow[b]{2}{*}{$\begin{array}{c}\text { Total } \\
n^{\mathrm{a}}\end{array}$} & \multirow[b]{2}{*}{ Cases of $A G I^{b}$} & \multirow[b]{2}{*}{ Attack rate (\%) } & \multicolumn{2}{|c|}{ Univariable analysis } & \multicolumn{2}{|c|}{ Multivariable analysis } \\
\hline & & & & $\begin{array}{c}\mathrm{RR} \\
(95 \% \mathrm{Cl})\end{array}$ & $\mathrm{p}$ value & $\begin{array}{c}\mathrm{RR} \\
(95 \% \mathrm{Cl})^{\mathrm{c}}\end{array}$ & $p$ value \\
\hline \multicolumn{8}{|c|}{ Respondent characteristics } \\
\hline \multicolumn{8}{|c|}{ Age (years) } \\
\hline $0-18$ & 311 & 6 & 1.9 & $0.69(0.22-2.2)$ & 0.530 & $0.63(0.21-1.9)$ & 0.412 \\
\hline $19-25$ & 363 & 15 & 4.1 & $1.5(0.71-3.1)$ & 0.293 & $1.2(0.55-2.6)$ & 0.661 \\
\hline $26-35$ & 863 & 24 & 2.8 & \multicolumn{2}{|l|}{ Ref } & \multicolumn{2}{|l|}{ Ref } \\
\hline $36-45$ & 784 & 22 & 2.8 & $1.01(0.64-1.6)$ & 0.969 & $1.01(0.59-1.7)$ & 0.964 \\
\hline$>45$ & 371 & 2 & 0.54 & $0.19(0.04-0.87)$ & 0.032 & $0.23(0.05-1.1)$ & 0.067 \\
\hline \multicolumn{8}{|l|}{ Sex } \\
\hline Male & 1,435 & 22 & 1.5 & \multicolumn{2}{|l|}{ Ref } & \multicolumn{2}{|l|}{ Ref } \\
\hline Female & 1,258 & 47 & 3.7 & $2.4(1.8-3.3)$ & 0.000 & $1.9(1.2-2.8)$ & 0.003 \\
\hline \multicolumn{8}{|c|}{ Current smoker } \\
\hline No & 2,506 & 65 & 2.6 & \multicolumn{2}{|l|}{ Ref } & \multicolumn{2}{|l|}{ NA } \\
\hline Yes & 185 & 4 & 2.2 & $0.8(0.35-2.0)$ & 0.681 & NA & \\
\hline \multicolumn{8}{|c|}{ Exposure to open water or obstacle run (past 3 months) } \\
\hline No & 1,746 & 56 & 3.2 & \multicolumn{2}{|l|}{ Ref } & \multicolumn{2}{|l|}{ Ref } \\
\hline Yes & 1,062 & 20 & 1.9 & $0.59(0.40-0.86)$ & 0.006 & $0.71(0.47-1.1)$ & 0.118 \\
\hline \multicolumn{8}{|c|}{ Use of medication (incl. antacids) ${ }^{d}$} \\
\hline No & 2,442 & 62 & 2.5 & \multicolumn{2}{|l|}{ Ref } & \multicolumn{2}{|l|}{ NA } \\
\hline Yes & 216 & 6 & 2.8 & $1.09(0.45-2.7)$ & 0.843 & NA & \\
\hline \multicolumn{8}{|c|}{ Use of antacids } \\
\hline No & 2,637 & 67 & 2.5 & \multicolumn{2}{|l|}{ Ref } & \multicolumn{2}{|l|}{ NA } \\
\hline Yes & 21 & 1 & 4.8 & $1.9(0.37-9.4)$ & 0.444 & NA & \\
\hline \multicolumn{8}{|l|}{ Allergies $^{e}$} \\
\hline No & 2,209 & 49 & 2.2 & \multicolumn{2}{|l|}{ Ref } & \multicolumn{2}{|l|}{ Ref } \\
\hline Yes & 449 & 19 & 4.2 & $1.9(1.3-2.8)$ & 0.001 & $1.7(1.2-2.5)$ & 0.004 \\
\hline \multicolumn{8}{|c|}{ Chronic diseases other than allergies ${ }^{f}$} \\
\hline No & 2,247 & 61 & 2.7 & \multicolumn{2}{|l|}{ Ref } & Ref & \\
\hline Yes & 411 & 7 & 1.7 & $0.63(0.43-0.91)$ & 0.014 & $0.51(0.33-0.79)$ & 0.003 \\
\hline
\end{tabular}

AGI: acute gastrointestinal infections; Cl: confidence interval; incl.: including; NA: not applicable; Ref: reference; RR: relative risk.

${ }^{a}$ Number of respondents who were exposed to the exposure variable.

${ }^{b}$ Number of respondents with gastrointestinal infections in the week after the event and exposure to the exposure variable.

${ }^{c}$ Adjusted for any exposure with $\mathrm{p}$ value $<0.05$ in the univariable analysis.

${ }^{d}$ For example, antibiotics or antacids.

e For example, hay fever or other self-defined allergies.

${ }^{f}$ Other than allergies; for example, diabetes, immune disorders and gastrointestinal diseases.

${ }^{\mathrm{g}}$ Official swimming water was officially approved for swimming by local authorities and non-official swimming water was not checked by local authorities.

Additional information on the questions asked in the questionnaire can be found in Supplement S1.

The questions on diarrhoea and vomiting were asked later on in the questionnaire and some respondents stopped before answering these questions. Only responses from those who answered these questions were included. 
Determinants for developing acute gastrointestinal infections in obstacle run participants, the Netherlands, 2017 ( $\mathrm{n}=2,808)$

\begin{tabular}{|c|c|c|c|c|c|c|c|}
\hline \multirow[b]{2}{*}{ Variables } & \multirow[b]{2}{*}{$\begin{array}{l}\text { Total } \\
\mathrm{n}^{\mathrm{a}}\end{array}$} & \multirow[b]{2}{*}{ Cases of $A G I^{b}$} & \multirow[b]{2}{*}{ Attack rate (\%) } & \multicolumn{2}{|c|}{ Univariable analysis } & \multicolumn{2}{|c|}{ Multivariable analysis } \\
\hline & & & & $\begin{array}{c}\mathrm{RR} \\
(95 \% \mathrm{Cl})\end{array}$ & $p$ value & $\begin{array}{c}\mathrm{RR} \\
(95 \% \mathrm{Cl})^{\mathrm{c}}\end{array}$ & $\mathrm{p}$ value \\
\hline \multicolumn{8}{|c|}{ Run characteristics } \\
\hline \multicolumn{8}{|c|}{ Distance (km) } \\
\hline $0-4.9$ & 190 & 3 & 1.6 & $0.54(0.11-2.6)$ & 0.446 & NA & \\
\hline $5-7.9$ & 1,093 & 32 & 2.9 & \multicolumn{2}{|l|}{ Ref } & \multicolumn{2}{|l|}{ NA } \\
\hline $8-10$ & 469 & 12 & 2.6 & $0.87(0.38-2.0)$ & 0.750 & NA & \\
\hline $10.1-15$ & 786 & 21 & 2.7 & $0.91(0.44-1.9)$ & 0.808 & NA & \\
\hline$>15.1$ & 270 & 8 & 3.0 & $1.01(0.48-2.2)$ & 0.975 & NA & \\
\hline \multicolumn{8}{|c|}{ Outside temperature $\left({ }^{\circ} \mathrm{C}\right)$} \\
\hline$\leq 15.0$ & o & 0 & NA & \multicolumn{2}{|l|}{ NA } & \multicolumn{2}{|l|}{ NA } \\
\hline $15.1-20.0$ & 1,149 & 40 & 3.5 & \multicolumn{2}{|l|}{ Ref } & \multicolumn{2}{|l|}{ NA } \\
\hline $20.1-25.0$ & 802 & 17 & 2.1 & $0.61(0.26-1.4)$ & 0.255 & NA & \\
\hline$\geq 25.1^{\circ} \mathrm{C}$ & 857 & 19 & 2.2 & $0.64(0.30-1.4)$ & 0.245 & NA & \\
\hline \multicolumn{8}{|c|}{ Official swimming water ${ }^{g}$} \\
\hline Non-official & 1,945 & 50 & 2.6 & \multicolumn{2}{|l|}{ Ref } & \multicolumn{2}{|l|}{ NA } \\
\hline Official & 411 & 11 & 2.7 & $1.04(0.49-2.2)$ & 0.918 & NA & \\
\hline Both & 452 & 15 & 3.3 & $1.3(0.70-2.4)$ & 0.419 & NA & \\
\hline \multicolumn{8}{|c|}{ Number of event days } \\
\hline 1 & 1,201 & 22 & 1.8 & \multicolumn{2}{|l|}{ Ref } & \multicolumn{2}{|l|}{ NA } \\
\hline 2 & 1,607 & 54 & 3.4 & $1.8(0.97-3.5)$ & 0.064 & NA & \\
\hline \multicolumn{8}{|c|}{ Animal faeces present on trail } \\
\hline No & 1,856 & 58 & 3.1 & \multicolumn{2}{|l|}{ Ref } & \multicolumn{2}{|l|}{ NA } \\
\hline Yes & 952 & 18 & 1.9 & $0.61(0.32-1.1)$ & 0.122 & NA & \\
\hline
\end{tabular}

AGI: acute gastrointestinal infections; $\mathrm{Cl}$ : confidence interval; incl.: including; NA: not applicable; Ref: reference; RR: relative risk.

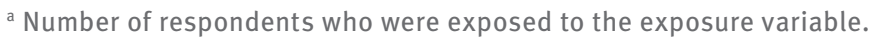

${ }^{b}$ Number of respondents with gastrointestinal infections in the week after the event and exposure to the exposure variable.

cAdjusted for any exposure with $\mathrm{p}$ value 0.05 in the univariable analysis.

${ }^{\mathrm{g}}$ Official swimming water was officially approved for swimming by local authorities and non-official swimming water was not checked by local authorities.

Additional information on the questions asked in the questionnaire can be found in Supplement S1.

The questions on diarrhoea and vomiting were asked later on in the questionnaire and some respondents stopped before answering these questions. Only responses from those who answered these questions were included.

Determinants associated with acute gastrointestinal infections

Of 2,831 respondents, 38 had AGI during or in the week before the obstacle run. The multilevel univariable analysis showed that 10 determinants were associated with the development of AGI following an obstacle run. In the multivariable model, five remained statistically significant, including swallowing mud (RR: $2.4 ; 95 \% \mathrm{Cl}$ : 1.2-4.9), having allergies (RR: $1.7 ; 95 \% \mathrm{Cl}: 1.2-2.5$ ) and being female (RR: $1.9 ; 95 \% \mathrm{Cl}: 1.2-2.8)$. Drinking alcohol on the day of an obstacle run and having chronic diseases other than allergies decreased the risk for AGI following an obstacle run (RR: $0.34 ; 95 \% \mathrm{Cl}: 0.16-0.71$ and RR: $0.51 ; 95 \% \mathrm{Cl}: 0.33-0.79$, respectively) (Table 3).

Determinants associated with skin infections

Five determinants were associated with the development of SI following an obstacle run in the univariable analysis and three remained statistically significant in the multivariable model. These included rinsing off after the run in a hot tub compared to running tap water and being female (RR: 2.2; 95\% Cl: $1.7-2.8$ and RR: 2.3; $95 \% \mathrm{Cl}: 1.3-3.9$, respectively). An outside temperature 


\section{TABLE 3C}

Determinants for developing acute gastrointestinal infections in obstacle run participants, the Netherlands, $2017(\mathrm{n}=2,808)$

\begin{tabular}{|c|c|c|c|c|c|c|c|}
\hline \multirow[b]{2}{*}{ Variables } & \multirow[b]{2}{*}{$\begin{array}{c}\text { Total } \\
n^{\mathrm{a}}\end{array}$} & \multirow[b]{2}{*}{ Cases of $A G I^{b}$} & \multirow[b]{2}{*}{ Attack rate (\%) } & \multicolumn{2}{|c|}{ Univariable analysis } & \multicolumn{2}{|c|}{ Multivariable analysis } \\
\hline & & & & $\begin{array}{c}\mathrm{RR} \\
(95 \% \mathrm{Cl})\end{array}$ & $p$ value & $\begin{array}{c}\mathrm{RR} \\
(95 \% \mathrm{Cl})^{c}\end{array}$ & value \\
\hline
\end{tabular}

\section{Specific exposure}

Type of shower water used

\begin{tabular}{|l|c|c|c|c|c|c|}
\hline Tap water & 2,364 & 59 & 2.5 & \multicolumn{2}{|c|}{ Ref } & NA \\
\hline Open water & 236 & 7 & 3.0 & $1.2(0.65-2.2)$ & 0.573 & NA \\
\hline Hot tub & 80 & 2 & 2.5 & $1.002(0.43-2.4)$ & 0.997 & NA \\
\hline Other & 35 & 1 & 2.9 & $1.1(0.37-3.5)$ & 0.813 & NA \\
\hline Show
\end{tabular}

Shower time (hours after run)

\begin{tabular}{|l|c|c|c|c|c|c|}
\hline$<1$ & 1,840 & 52 & 2.8 & \multicolumn{2}{|c|}{ Ref } & NA \\
\hline $1-3$ & 706 & 15 & 2.1 & $0.75(0.43-1.3)$ & 0.313 & NA \\
\hline$>3$ & 174 & 2 & 1.2 & $0.41(0.17-0.95)$ & 0.037 & NA \\
\hline
\end{tabular}

Toilet used

\begin{tabular}{|l|c|c|c|c|c|c|}
\hline No & 862 & 18 & 2.1 & \multicolumn{2}{|c|}{ Ref } & NA \\
\hline Yes & 1,856 & 51 & 2.8 & $1.3(0.80-2.2)$ & 0.276 & NA \\
\hline Wat
\end{tabular}

Water in mouth

\begin{tabular}{|l|c|c|c|c|c|c|c|}
\hline No & 1,092 & 16 & 1.5 & \multicolumn{2}{|c|}{ Ref } & \multicolumn{2}{|c|}{ Ref } \\
\hline Yes, not swallowed & 1,200 & 35 & 2.9 & $2.0(1.1-3.8)$ & 0.036 & $2.0(0.94-4.1)$ & 0.071 \\
\hline Yes, swallowed & 440 & 19 & 4.3 & $2.9(1.4-6.2)$ & 0.004 & $2.2(0.97-5.2)$ & 0.061 \\
\hline
\end{tabular}

\begin{tabular}{|l|c|c|c|c|c|c|c|}
\hline Mud in mouth & 1,762 & 39 & 2.2 & \multicolumn{5}{|c|}{ Ref } & \multicolumn{2}{|c|}{ Ref } \\
\hline No & 882 & 24 & 2.7 & $1.2(0.8-1.9)$ & 0.350 & $1.02(0.61-1.7)$ & 0.946 \\
\hline Yes, not swallowed & 85 & 7 & 8.2 & $3.7(1.8-7.7)$ & 0.000 & $2.4(1.2-4.9)$ & 0.015 \\
\hline Yes, swallowed & &
\end{tabular}

\section{Consumed beverages}

Drinking water from organisation

\begin{tabular}{|c|c|c|c|c|c|c|c|}
\hline No & 459 & 7 & 1.5 & \multicolumn{2}{|c|}{ Ref } & \multirow{2}{*}{\multicolumn{2}{|c|}{$\begin{array}{l}\text { NA } \\
\text { NA }\end{array}$}} \\
\hline Yes & 2,229 & 62 & 2.8 & $1.8(0.79-4.2)$ & 0.162 & & \\
\hline \multicolumn{8}{|c|}{ Soda } \\
\hline No & 2,130 & 60 & 2.8 & \multicolumn{2}{|c|}{ Ref } & \multicolumn{2}{|l|}{ NA } \\
\hline Yes & 558 & 9 & 1.6 & $0.57(0.29-1.1)$ & 0.105 & \multicolumn{2}{|l|}{ NA } \\
\hline \multicolumn{8}{|c|}{ Energy drink } \\
\hline No & 2,165 & 53 & 2.5 & \multicolumn{2}{|l|}{ Ref } & \multicolumn{2}{|l|}{ NA } \\
\hline Yes & 523 & 16 & 3.1 & $1.2(0.73-2.1)$ & 0.419 & \multicolumn{2}{|l|}{ NA } \\
\hline \multicolumn{8}{|c|}{ Alcoholic beverage } \\
\hline No & 2,031 & 62 & 3.1 & \multicolumn{2}{|c|}{ Ref } & \multicolumn{2}{|l|}{ Ref } \\
\hline Yes & 657 & 7 & 1.1 & $0.35(0.18-0.67)$ & 0.002 & $0.34(0.16-0.71)$ & 0.004 \\
\hline
\end{tabular}

\begin{tabular}{|l|c|c|c|c|c|c|}
\hline Coffee/tea & 2,196 & 55 & 2.5 & \multicolumn{2}{|c|}{ Ref } & NA \\
\hline No & 492 & 14 & 2.9 & $1.1(0.62-2.1)$ & 0.682 & NA \\
\hline Yes & \multicolumn{7}{|c|}{ Ref } & NA \\
\hline Juice & 1,791 & 39 & 2.2 & & NA \\
\hline No & 58 & 2 & 3.5 & $1.6(0.27-9.4)$ & 0.613 & n \\
\hline Yes &
\end{tabular}

AGI: acute gastrointestinal infections; $\mathrm{Cl}$ : confidence interval; incl.: including; NA: not applicable; Ref: reference; RR: relative risk.

${ }^{a}$ Number of respondents who were exposed to the exposure variable.

${ }^{b}$ Number of respondents with gastrointestinal infections in the week after the event and exposure to the exposure variable.

c Adjusted for any exposure with $\mathrm{p}$ value 0.05 in the univariable analysis.

Additional information on the questions asked in the questionnaire can be found in Supplement S1.

The questions on diarrhoea and vomiting were asked later on in the questionnaire and some respondents stopped before answering these questions. Only responses from those who answered these questions were included. 
of $>25^{\circ} \mathrm{C}$ decreased the risk for SI (RR: 0.53; $95 \% \mathrm{Cl}$ : 0.31-0.91) (Table 4).

Determinants associated with respiratory infections Five determinants were associated with the development of RI following an obstacle run in the univariable analysis and three remained statistically significant in the multivariable model. These included being aged 19-25 years (compared to 26-35 years) and being female (RR: $1.8 ; 95 \% \mathrm{Cl}: 1.2-2.9$ and RR: $2.1 ; 95 \% \mathrm{Cl}$ : $1.6-3.0$, respectively). Being aged $\geq 45$ years (compared to $26-35$ years) decreased the risk for developing RI (RR: $0.31 ; 95 \% \mathrm{Cl}$ : 0.16-0.60) (Table 5).

\section{Clinical microbiological results}

The laboratory received stool specimens from 111 respondents from 17 obstacle runs, of which 13 tested positive for six different pathogens (no participant tested positive for the same pathogen as another participant in the same run). These pathogens were sapovirus $(n=5)$, norovirus $(n=4)$, Shigella spp. $(n=1)$, enterohaemorrhagic Escherichia coli (EHEC) $(\mathrm{n}=1)$, Campylobacter jejuni $(\mathrm{n}=1)$ and Giardia lamblia $(\mathrm{n}=2)$.

Four of these pathogens (norovirus, sapovirus, G. lamblia and $C$. jejuni) explained the acute gastrointestinal complaints of seven respondents, with two reporting gastrointestinal symptoms before the obstacle run and five after. The EHEC-positive respondent reported headache and red bumps on the skin. The other six positive respondents ( $G$. lamblia, norovirus, sapovirus, Shigella spp.) did not report any health complaints.

\section{Discussion}

To our knowledge, this is the first study investigating the incidence of AGI, SI and RI following participation in an obstacle run, as well as risk factors. Not many infectious diseases were reported by respondents in the questionnaire of this study (in $2.7 \%-5.8 \%$ of respondents), which suggests a low risk for infection after participation in an obstacle run.

The primary care continuous morbidity surveillance system estimated that from April to October 2017, 2\% of the Dutch adult population had consulted a general practitioner (GP) for an $\mathrm{AGI}$ and $4 \%$ for an RI [21]; no primary care data was available for SI. Although the incidences of AGI and RI from our study are seemingly comparable to those obtained from primary care in the Netherlands, the latter only reflects diseases in people who attended a GP and, therefore, may not be generalisable to the general population.

In this study, the ingestion of mud was associated with AGI, supporting current advice offered to participants, i.e. to avoid ingesting water/mud by trying to keep their mouths closed during obstacle runs. This advice arose due to similar findings regarding the risk for infectious diseases observed in other (outbreak) investigations related to events that include water or mud, e.g. mountain bike events and city swims [7-14]. We acknowledge this is not always feasible due to the high oxygen demand during intense activity.

Previous studies have also found a protective effect of alcohol on the risk of developing AGI [22-25]. This effect could be attributed to the ethanol and antioxidants or other substances in the alcoholic beverages [25]. However, as we did not collect information on the number of alcoholic beverages consumed by participants, nor when they consumed it (i.e. before, during or after the obstacle run), the protective association we found should be interpreted with caution.

We found that respondents with allergies were more at risk for AGI in multivariable analysis and those with a chronic disease other than allergies were more at risk for SI and RI in univariable analysis. We also found that having one or more chronic diseases had a protective effect on AGI. This could partially be explained by the non-specific definition of chronic diseases in our study. Several chronic diseases (e.g. eczema and diabetes) were grouped together since the number of each reported disease was too low to analyse separately.

Proper handwashing is a very effective measure for the prevention of infectious disease [26]. In our study, we found that 13 obstacle runs did not have adequate handwashing facilities, e.g. with running water, soap and paper towels. Food was distributed at 14 obstacle runs and, as it is not practical for participants to wash their hands during an obstacle run (and they are likely covered in mud when the food is distributed), unpeeled fruits and packaged foods may be better options.

\section{Strengths and limitations}

Due to the large study population and inclusion of several different obstacle runs, we believe the results could be relevant to other events with similar environmental conditions. Further, as several obstacle runs were investigated, the identified risk factors may be more generalisable.

There are several limitations with this study. First, it is likely that there was self-selection bias, wherein participants who developed symptoms after an obstacle run were more likely to take part in the study than those who remained healthy. This may have resulted in an overestimation of the attack rate for AGI, SI and RI.

Second, recall bias may have occurred, as participants received the questionnaire 1 week after participating in the run and exposure to potential risk factors may have been recalled better by respondents who developed symptoms. Although this bias is expected to be minimal, the RR and risk factors identified may have been overestimated.

Third, it is known that women tend to report poorer health than men on self-reported health indicators 
TABLE 4

Determinants for developing skin infections in obstacle run participants, the Netherlands, $2017(\mathrm{n}=2,790)$

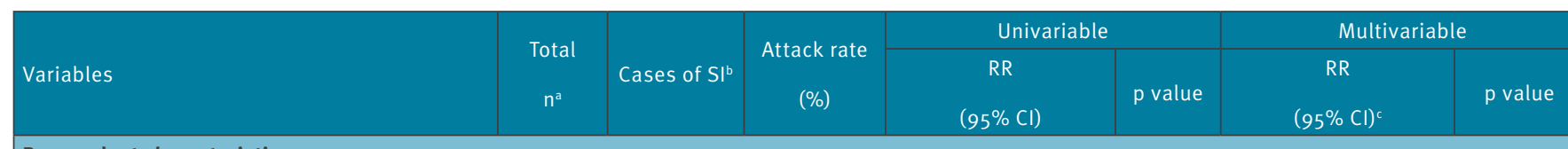

Respondent characteristics

\section{Age (years)}

\begin{tabular}{|c|c|c|c|c|c|c|c|}
\hline $0-18$ & 311 & 11 & 3.5 & $0.92(0.48-1.8)$ & 0.819 & $1.2(0.58-2.5)$ & 0.607 \\
\hline $19-25$ & 363 & 21 & 5.8 & $1.5(0.94-2.4)$ & 0.089 & $1.4(0.84-2.3)$ & 0.202 \\
\hline $26-35$ & 863 & 33 & 3.8 & \multicolumn{2}{|l|}{ Ref } & \multicolumn{2}{|l|}{ Ref } \\
\hline $36-45$ & 784 & 25 & 3.2 & $0.83(0.46-1.5)$ & 0.555 & $0.92(0.50-1.7)$ & 0.797 \\
\hline$>45$ & 371 & 9 & 2.4 & $0.63(0.38-1.1)$ & 0.081 & $0.76(0.42-1.4)$ & 0.360 \\
\hline \multicolumn{8}{|l|}{ Sex } \\
\hline Male & 1,435 & 31 & 2.2 & \multicolumn{2}{|l|}{ Ref } & \multicolumn{2}{|l|}{ Ref } \\
\hline Female & 1,258 & 68 & 5.4 & $2.5(1.4-4.6)$ & 0.003 & $2.3(1.3-3.9)$ & 0.004 \\
\hline \multicolumn{8}{|c|}{ Exposure to open water or obstacle run (past 3 months) } \\
\hline No & 1,733 & 73 & 4.2 & \multicolumn{2}{|l|}{ Ref } & \multicolumn{2}{|l|}{ NA } \\
\hline Yes & 1,057 & 30 & 2.8 & $0.67(0.39-1.2)$ & 0.166 & \multicolumn{2}{|l|}{ NA } \\
\hline \multicolumn{8}{|c|}{ Allergies $^{d}$} \\
\hline No & 2,209 & 76 & 3.4 & \multicolumn{2}{|l|}{ Ref } & \multicolumn{2}{|l|}{ NA } \\
\hline Yes & 449 & 22 & 4.9 & $1.4(0.95-2.1)$ & 0.087 & \multicolumn{2}{|l|}{ NA } \\
\hline No & 2,247 & 74 & 3.3 & \multicolumn{2}{|l|}{ Ref } & \multicolumn{2}{|l|}{ Ref } \\
\hline Yes & 411 & 24 & 5.8 & $1.8(1.03-3.1)$ & 0.040 & $1.7(0.97-2.8)$ & 0.065 \\
\hline
\end{tabular}

Run characteristics

Outside temperature $\left({ }^{\circ} \mathrm{C}\right)$

\begin{tabular}{|c|c|c|c|c|c|c|c|}
\hline$\leq 15.0$ & 0 & 0 & NA & \multicolumn{2}{|l|}{ NA } & \multicolumn{2}{|l|}{ NA } \\
\hline $15.1-20.0$ & 1,137 & 62 & 5.5 & \multicolumn{2}{|l|}{ Ref } & \multicolumn{2}{|l|}{ Ref } \\
\hline $20.1-25.0$ & 80 & 20 & 2.5 & $0.46(0.23-0.89)$ & 0.022 & $0.56(0.31-1.005)$ & 0.052 \\
\hline$\geq 25.1^{\circ} \mathrm{C}$ & 853 & 21 & 2.5 & $0.45(0.23-0.90)$ & 0.023 & $0.53(0.31-0.91)$ & 0.022 \\
\hline
\end{tabular}

\section{Number of event days}

\begin{tabular}{|c|c|c|c|c|c|c|c|}
\hline 1 & 1,193 & 54 & $4 \cdot 5$ & \multicolumn{2}{|l|}{ Ref } & \multicolumn{2}{|l|}{ NA } \\
\hline 2 & 1,597 & 49 & 3.1 & $0.68(0.30-1.5)$ & 0.341 & \multicolumn{2}{|l|}{ NA } \\
\hline \multicolumn{8}{|l|}{ Animal faeces present on trail } \\
\hline Yes & 949 & 42 & $4 \cdot 4$ & $1.3(0.64-2.8)$ & 0.436 & \multicolumn{2}{|l|}{ NA } \\
\hline \multicolumn{8}{|l|}{ Specific exposures } \\
\hline \multicolumn{8}{|l|}{ Type of shower water used } \\
\hline Tap water & 2,364 & 76 & 3.2 & \multicolumn{2}{|l|}{ Ref } & \multicolumn{2}{|c|}{ Ref } \\
\hline Open water & 236 & 16 & 6.8 & $2.1(0.80-5.6)$ & 0.133 & $1.5(0.67-3.4)$ & 0.319 \\
\hline Hot tub & 80 & 6 & 7.5 & $2.3(1.6-3.4)$ & 0.000 & $2.2(1.7-2.8)$ & 0.000 \\
\hline Other & 35 & 1 & 2.9 & $0.89(0.10-8.1)$ & 0.916 & $0.66(0.08-5.4)$ & 0.696 \\
\hline \multicolumn{8}{|l|}{ Shower time (hours after run) } \\
\hline$<1$ & 1,840 & 61 & 3.3 & \multicolumn{2}{|l|}{ Ref } & \multicolumn{2}{|l|}{ NA } \\
\hline $1-3$ & 706 & 32 & $4 \cdot 5$ & $1.4(0.96-2.0)$ & 0.086 & \multicolumn{2}{|l|}{ NA } \\
\hline \multicolumn{8}{|l|}{ Clothes worn } \\
\hline Long pants, long sleeves & 333 & 14 & 4.2 & \multicolumn{2}{|l|}{ Ref } & \multicolumn{2}{|l|}{ NA } \\
\hline $\begin{array}{l}\text { Long pants, short sleeves/short pants, long } \\
\text { sleeves combined }\end{array}$ & 1,420 & 52 & 3.7 & $0.87(0.49-1.6)$ & 0.642 & \multicolumn{2}{|l|}{ NA } \\
\hline Short pants, short sleeves & 889 & 30 & 3.4 & $0.80(0.35-1.8)$ & 0.603 & \multicolumn{2}{|l|}{ NA } \\
\hline Other & 78 & 3 & 3.9 & $0.91(0.29-2.9)$ & 0.880 & \multicolumn{2}{|l|}{ NA } \\
\hline
\end{tabular}

Cl: confidence interval; NA: not applicable; Ref: reference; RR: relative risk; SI: skin infections.

${ }^{a}$ Number of respondents who were exposed to the exposure variable.

${ }^{b}$ Number of respondents with skin infections in the week after the event and exposure to the exposure variable.

${ }^{c}$ Adjusted for any exposure with $\mathrm{p}$ value $<0.05$ in the univariable analysis.

${ }^{\mathrm{d}}$ For example, hay fever or other self-defined allergies.

e Other than allergies; for example, diabetes, immune disorders and gastrointestinal diseases.

Additional information on the questions asked in the questionnaire can be found in Supplement $\mathrm{S} 1$.

The question on skin infections was asked later on in the questionnaire and some respondents stopped before answering this question. Only responses from those who answered this question were included. 


\section{TABLE 5A}

Determinants for developing respiratory infections in obstacle run participants, the Netherlands, $2017(\mathrm{n}=2,790)$

\begin{tabular}{|c|c|c|c|c|c|c|c|}
\hline \multirow[b]{2}{*}{ Variables } & \multirow[b]{2}{*}{$\begin{array}{c}\text { Total } \\
n^{\mathrm{a}}\end{array}$} & \multirow[b]{2}{*}{ Cases of $\mathrm{R}^{\mathrm{b}}$} & \multirow[b]{2}{*}{$\begin{array}{c}\text { Attack rate } \\
\text { (\%) }\end{array}$} & \multicolumn{2}{|c|}{ Univariable } & \multicolumn{2}{|c|}{ Multivariable } \\
\hline & & & & $\begin{array}{c}\text { RR } \\
(95 \% \mathrm{Cl})\end{array}$ & $\mathrm{p}$ value & $\begin{array}{c}\mathrm{RR} \\
(95 \% \mathrm{Cl})^{c}\end{array}$ & $\mathrm{p}$ value \\
\hline \multicolumn{8}{|c|}{ Respondent characteristics } \\
\hline \multicolumn{8}{|c|}{ Age (years) } \\
\hline $0-18$ & 311 & 20 & 6.4 & $1.2(0.88-1.7)$ & 0.245 & $1.4(0.98-2.0)$ & 0.061 \\
\hline $19-25$ & 363 & 38 & 10 & $2.0(1.2-3.1)$ & 0.003 & $1.8(1.2-2.9)$ & 0.011 \\
\hline $26-35$ & 863 & 46 & 5.3 & \multicolumn{2}{|l|}{ Ref } & \multicolumn{2}{|l|}{ Ref } \\
\hline $36-45$ & 784 & 41 & 5.2 & $0.98(0.59-1.6)$ & 0.941 & $1.1(0.64-1.7)$ & 0.842 \\
\hline$>45$ & 371 & 5 & 1.4 & $0.25(0.13-0.48)$ & 0.000 & $0.31(0.16-0.60)$ & 0.000 \\
\hline \multicolumn{8}{|l|}{ Sex } \\
\hline Male & 1,435 & 47 & 3.3 & \multicolumn{2}{|l|}{ Ref } & \multicolumn{2}{|l|}{ Ref } \\
\hline Female & 1,258 & 103 & 8.2 & $2.5(1.9-3.4)$ & 0.000 & $2.1(1.6-3.0)$ & 0.000 \\
\hline \multicolumn{8}{|c|}{ Current smoker } \\
\hline No & 2,506 & 135 & 5.4 & \multicolumn{2}{|l|}{ Ref } & \multicolumn{2}{|l|}{ NA } \\
\hline Yes & 185 & 15 & 8.1 & $1.5(0.92-2.5)$ & 0.107 & \multicolumn{2}{|l|}{ NA } \\
\hline \multicolumn{8}{|c|}{ Exposure to open water or obstacle run (past 3 months) } \\
\hline No & 1733 & 109 & 6.3 & \multicolumn{2}{|l|}{ Ref } & \multicolumn{2}{|l|}{ NA } \\
\hline Yes & 1057 & 54 & 5.1 & $0.81(0.56-1.2)$ & 0.268 & \multicolumn{2}{|l|}{ NA } \\
\hline \multicolumn{8}{|c|}{ Use of medication (incl. antacids) ${ }^{d}$} \\
\hline No & 2,442 & 137 & 5.6 & \multicolumn{2}{|l|}{ Ref } & \multicolumn{2}{|l|}{ NA } \\
\hline Yes & 216 & 11 & 5.1 & $0.91(0.52-1.6)$ & 0.733 & \multicolumn{2}{|l|}{ NA } \\
\hline \multicolumn{8}{|c|}{ Use of medication for allergies } \\
\hline No & 2,604 & 142 & 5.5 & Ref & & NA & \\
\hline Yes & 54 & 6 & 11 & $2.0(0.90-4.6)$ & 0.087 & NA & \\
\hline Use of med & & & & & & & \\
\hline No & 2,611 & 145 & 5.6 & Ref & & NA & \\
\hline Yes & 47 & 3 & 6.4 & $1.1(0.42-3.1)$ & 0.784 & NA & \\
\hline Allergies $^{\mathrm{e}}$ & & & & & & & \\
\hline No & 2,209 & 109 & 4.9 & Ref & & Ref & \\
\hline Yes & 449 & 39 & 8.7 & $1.8(1.1-2.8)$ & 0.014 & $1.6(0.99-2.6)$ & 0.054 \\
\hline Chronic dis & & & & & & & \\
\hline No & 2,247 & 116 & 5.2 & Ref & & NA & \\
\hline Yes & 411 & 32 & 7.8 & $1.5(0.99-2.3)$ & 0.054 & NA & \\
\hline Run charac & & & & & & & \\
\hline Outside ter & & & & & & & \\
\hline$\leq 15.0$ & 0 & 0 & $\mathrm{NA}$ & NA & & NA & \\
\hline $15.1-20.0$ & 1,137 & 78 & 6.9 & Ref & & NA & \\
\hline $20.1-25.0$ & 800 & 50 & 6.3 & $0.91(0.60-1.4)$ & 0.667 & NA & \\
\hline$\geq 25.1$ & 853 & 35 & 4.1 & $0.60(0.26-1.4)$ & 0.235 & NA & \\
\hline
\end{tabular}

$\mathrm{Cl}$ : confidence interval; incl.: including; NA: not applicable; Ref: reference; RI: respiratory infections; RR: relative risk.

a Number of respondents who were exposed to the exposure variable.

${ }^{\mathrm{b}}$ Number of respondents with respiratory infections in the week after the event and exposure to the exposure variable.

${ }^{c}$ Adjusted for any exposure with $\mathrm{p}$ value 0.05 in the univariable analysis.

${ }^{d}$ For example, antibiotics or antacids.

e For example, hay fever or other self-defined allergies.

${ }^{f}$ Other than allergies; for example, diabetes, immune disorders or gastrointestinal diseases.

Additional information on the questions asked in the questionnaire can be found in Supplement S1.

The question on respiratory infections was asked later on in the questionnaire and some respondents stopped before answering this question. Only responses from those who answered this question were included. 
Determinants for developing respiratory infections in obstacle run participants, the Netherlands, $2017(\mathrm{n}=2,790)$

\begin{tabular}{|c|c|c|c|c|c|c|c|}
\hline \multirow[b]{2}{*}{ Variables } & \multirow[b]{2}{*}{$\begin{array}{c}\text { Total } \\
\mathrm{n}^{\mathrm{a}}\end{array}$} & \multirow[b]{2}{*}{ Cases of $\mathrm{RI}^{\mathrm{b}}$} & \multirow[b]{2}{*}{$\begin{array}{c}\text { Attack rate } \\
(\%)\end{array}$} & \multicolumn{2}{|c|}{ Univariable } & \multicolumn{2}{|c|}{ Multivariable } \\
\hline & & & & $\begin{array}{c}\mathrm{RR} \\
(95 \% \mathrm{Cl})\end{array}$ & $p$ value & $\begin{array}{c}\mathrm{RR} \\
(95 \% \mathrm{Cl})^{\mathrm{c}}\end{array}$ & $p$ value \\
\hline \multicolumn{8}{|l|}{ Run characteristics } \\
\hline \multicolumn{8}{|l|}{ Rain on event day } \\
\hline Heavy rain & 0 & 0 & NA & \multicolumn{2}{|l|}{ NA } & \multicolumn{2}{|l|}{ NA } \\
\hline Light rain & 663 & 41 & 6.2 & Ref & & \multicolumn{2}{|l|}{ NA } \\
\hline No rain & 2,127 & 122 & 5.7 & $0.93(0.58-1.5)$ & 0.750 & \multicolumn{2}{|l|}{ NA } \\
\hline \multicolumn{8}{|l|}{ Number of event days } \\
\hline 1 & 1,193 & 77 & 6.5 & \multicolumn{2}{|l|}{ Ref } & \multicolumn{2}{|l|}{ NA } \\
\hline 2 & 1,597 & 86 & 5.4 & $0.83(0.51-1.4)$ & 0.462 & \multicolumn{2}{|l|}{ NA } \\
\hline \multicolumn{8}{|l|}{ Specific exposures } \\
\hline \multicolumn{8}{|c|}{ Type of shower water used } \\
\hline Tap water & 2,364 & 129 & 5.5 & \multicolumn{2}{|l|}{ Ref } & \multicolumn{2}{|l|}{ Ref } \\
\hline Open water & 236 & 18 & 7.6 & $1.4(1.1-1.8)$ & 0.016 & $1.3(0.84-2.0)$ & 0.246 \\
\hline Hot tub & 80 & 4 & 5.0 & $0.92(0.54-1.6)$ & 0.749 & $1.2(0.64-2.1)$ & 0.626 \\
\hline Other & 35 & 1 & 2.9 & $0.52(0.05-5.2)$ & 0.579 & $0.51(0.06-4.3)$ & 0.536 \\
\hline \multicolumn{8}{|l|}{ Water in mouth } \\
\hline No & 1,092 & 53 & 4.9 & \multicolumn{2}{|l|}{ Ref } & \multicolumn{2}{|l|}{ NA } \\
\hline Yes, not swallowed & 1,200 & 75 & 6.3 & $1.3(0.84-2.0)$ & 0.240 & \multicolumn{2}{|l|}{ NA } \\
\hline Yes, swallowed & 440 & 25 & 5.7 & $1.2(0.78-1.8)$ & 0.451 & \multicolumn{2}{|l|}{ NA } \\
\hline \multicolumn{8}{|l|}{ Mud in mouth } \\
\hline No & 1,762 & 96 & 5.5 & \multicolumn{2}{|l|}{ Ref } & \multicolumn{2}{|l|}{ NA } \\
\hline Yes, not swallowed & 882 & 52 & 5.9 & $1.1(0.74-1.6)$ & 0.683 & \multicolumn{2}{|l|}{ NA } \\
\hline Yes, swallowed & 85 & 5 & 5.9 & $1.1(0.45-2.6)$ & 0.863 & \multicolumn{2}{|l|}{ NA } \\
\hline
\end{tabular}

$\mathrm{Cl}$ : confidence interval; incl.: including; NA: not applicable; Ref: reference; RI: respiratory infections; RR: relative risk.

${ }^{a}$ Number of respondents who were exposed to the exposure variable.

${ }^{b}$ Number of respondents with respiratory infections in the week after the event and exposure to the exposure variable.

${ }^{\mathrm{c}}$ Adjusted for any exposure with $\mathrm{p}$ value 0.05 in the univariable analysis.

${ }^{\mathrm{d}}$ For example, antibiotics or antacids.

e For example, hay fever or other self-defined allergies.

${ }^{f}$ Other than allergies; for example, diabetes, immune disorders or gastrointestinal diseases.

Additional information on the questions asked in the questionnaire can be found in Supplement S1.

The question on respiratory infections was asked later on in the questionnaire and some respondents stopped before answering this question. Only responses from those who answered this question were included.

[27], which may explain the high incidence on AGI, SI and $\mathrm{RI}$ reported among women.

Fourth, the incidence of infectious diseases reported in this study may have been overestimated, as not all symptoms reported are exclusive to AGI, RI and SI. For example, respiratory disease can occur due to allergies. It was not possible, however, to differentiate between the underlying causes of certain symptoms, which could have resulted in an overestimation of the incidence of AGI, RI and SI in this study. Further, respondents were asked about infectious disease symptoms that occurred following the obstacle run, so the symptoms reported may not have been caused by the event.

Fifth, due to the design of the study, the results of the microbiological analysis were not compared with a control group. In future studies, however, stool sample testing should be done directly after onset of symptoms and a control group should be included so the results can be compared and used as part of an outbreak investigation, should the need arise.

Finally, we investigated frequencies of disease in this study, but diseases such as tularaemia and leptospirosis-which have longer incubation periods than the 
time given to complete the questionnaire-might have been missed. However, as these are rare diseases in the Netherlands and the symptoms are not widely recognised, it is unlikely that these diseases would have been identified even with a longer time period allocated to the questionnaire.

\section{Conclusion}

Our study suggests that the risk of contracting AGI, SI or RI following participation in an obstacle run is low. However, the potential for disease outbreaks related to such events can be high, as seen in previous studies [7-14]. To limit the occurrence of outbreaks and sporadic infections, we recommend that organisers of obstacle runs inform participants of infectious disease risks and potential preventive measures they could take, e.g. practicing good hand hygiene, not participating if they are ill, not swallowing mud and showering directly after the run. In addition, we recommend that organisers adequately facilitate these preventive measures, e.g. by installing proper handwashing and shower facilities and only distributing foods that are unpeeled/packaged during the obstacle run. Based on visual inspections, we also recommend that organisers fulfil the national hygiene guidelines regarding the toilets and showers around the obstacle run course.

\section{Acknowledgements}

This study was supported by a grant from the Centre for Infectious Disease Control of the National Institute for Public Health and the Environment (RIVM), the Netherlands. We would like to thank all organisations and respondents that participated in this study. It became clear to us that organisations were more than willing to participate in protecting their participants. Also, we would like to thank Helen Ewalts for developing the hygiene checklist we used for the inspections and Gabriella Morroy for her contribution to the final version of the article.

\section{Conflict of interest}

None declared.

\section{Authors' contributions}

Conceptualisation: DO, AD, EF. Investigation: EB, DO, AD. Microbiological analysis: AL. Data curation: EB. Data analysis and interpretation: EB, AD, AT. Writing original draft: EB. Writing, review and editing: EB, DO, AD, AT, AL, EF. Supervision: AD.

\section{References}

1. Obstakels.com. Wat is een obstacle run. Facts feiten. [What is an obstacle run. Facts]. Lieshout: Obstakels.com. [Accessed: 4 Sept 2019]. Dutch. Available from: https://obstakels.com/ wat-is-een-obstacle-run/facts-feiten/<ref/

2. Strong Viking. Legal. Policies and conditions. Website. [Accessed: 4 Sept 2019]. Dutch. Available from: https:// strongviking.com/nl/condities/

3. Obstakels.com. Obstacle Run Kalender. [Obstacle run calendar]. Lieshout: Obstakels.com. [Accessed: 29 Dec 2017]. Dutch. Available from: https://obstakels.com/kalender/
4. Terrain Race. What is an obstacle course race? Website. [Accessed: 4 Sept 2019]. Available from: https://terrainrace. com/terrain-obstacle-course/

5. Obstakels.com. Wat is nou een survivalrun? [What is a survival run?]. Lieshout: Obstakels.com. [Accessed 13 Aug 2018]. Dutch. Available from: https://obstakels.com/2015/11/24/ wat-is-nou-een-survivalrun/

6. All Terrain. What is a survival run? Website. [Accessed: 4 Sept 2019]. Available from: https://allterrain.nl/ what-is-a-survivalrun/

7. Griffiths SL, Salmon RL, Mason BW, Elliott C, Thomas DRH, Davies C. Using the internet for rapid investigation of an outbreak of diarrhoeal illness in mountain bikers. Epidemiol Infect. 2010;138(12):1704-11. https://doi.org/10.1017/ So950268810001561 PMID: 20587125

8. Hall V, Taye A, Walsh B, Maguire H, Dave J, Wright A, et al. A large outbreak of gastrointestinal illness at an open-water swimming event in the River Thames, London. Epidemiol Infect. 2017;145(6):1246-55. https://doi.org/10.1017/ So950268816003393 PMID: 28162113

9. Joosten R, Sonder G, Parkkali S, Brandwagt D, Fanoy E, Mughini-Gras L, et al. Risk factors for gastroenteritis associated with canal swimming in two cities in the Netherlands during the summer of 2015: A prospective study. PLoS One. 2017;12(4):e0174732. https://doi.org/10.1371/ journal.pone.0174732 PMID: 28369101

10. Mexia R, Vold L, Heier BT, Nygård K. Gastrointestinal disease outbreaks in cycling events: are preventive measures effective? Epidemiol Infect. 2013;141(3):517-23. https://doi.org/10.1017/ So950268812000817 PMID: 22591923

11. Six C, Aboukais S, Giron S, D’Oliveira JC, Peloux-Petiot F, Franke F, et al. Outbreak of diarrhoeal illness in participants in an obstacle adventure race, Alpes-Maritimes, France, June 2015. Euro Surveill. 2016;21(23):30253. https://doi. org/10.2807/1560-7917.ES.2016.21.23.30253 PMID: 27311488

12. Stuart TL, Sandhu J, Stirling R, Corder J, Ellis A, Misa $P$, et al. Campylobacteriosis outbreak associated with ingestion of mud during a mountain bike race. Epidemio Infect. 2010;138(12):1695-703. https://doi.org/10.1017/ So95026881000049X PMID: 20334726

13. Zeigler M, Claar C, Rice D, Davis J, Frazier T, Turner A, et al. Centers for Disease Control and Prevention (CDC). Outbreak of campylobacteriosis associated with a long-distance obstacle adventure race--Nevada, October 2012. MMWR Morb Mortal Wkly Rep. 2014;63(17):375-8. PMID: 24785983

14. Hintaran AD, Kliffen SJ, Lodder W, Pijnacker R, Brandwagt $\mathrm{D}$, van der $\mathrm{Bij} \mathrm{AK}$, et al. Infection risks of city canal swimming events in the Netherlands in 2016. PLoS One. 2018;13(7):e0200616. https://doi.org/10.1371/journal. pone.0200616 PMID: 30052633

15. Zijlstra M, Hulsker CCC, Fanoy EB, Pijnacker R, Kraaijeveld A, Koene MG), et al. [Tularaemia in a boy following participation in a mud race]. Ned Tijdschr Geneeskd. 2017;160(o):D1180. PMID: 28466800

16. Uiterwijk M, De Rosa M, Friesema I, Valkenburgh S, Roest $\mathrm{H}$, van Pelt W. Staat van Zoönosen 2015. [State of Zoonoses 2015]. Bilthoven: National Institute for Public Health and the Environment (RIVM); 2016. Dutch.

17. De Schrijver K, Berghs R, Van Esbroeck M, Vlieghe E, Flipse W. Leptospirose bij deelnemers aan een obstakelloop in Nijlen in 2015. [Leptospirosis among participants in an obstacle course in Nijlen in 2015]. Vlaams infectieziektebulletin. 2017;2017(4):6-11.

18. National Institute for Public Health and the Environment (RIVM). Gastroenteritis and food poisoning (foodborne). Bilthoven: RIVM; [Accessed 12 Sep 2019]. Dutch. Available from: https://lci.rivm.nl/draaiboeken/ gastro-enteritis-en-voedselvergiftigingen

19. National Institute for Public Health and the Environment (RIVM). Article 26 notifications Wpg settings. Bilthoven: RIVM; [Accessed 12 Sep 2019]. Dutch. Available from: https://Ici.rivm. $\mathrm{nl} /$ draaiboeken/artikel-26-meldingen-wpg-instellingen

20. Collector Innovative Surveys. Vragenlijsten [questionnaires]. Survalyzer AG [Accessed in 2017]. Dutch Available from: https://login.premiumuser.datacoll.nl/

21. Hooiveld M, Donkers GA, Korevaar JC. Wekelijkse surveillance cijfers. Nivel Zorgregistraties eerste lijn. [Weekly surveillance figures. Nivel Primary Care Registration]. Utrecht: Nivel; 2018. Dutch. Available from: www.nivel.nl/surveillance.

22. Bellido-Blasco JB, Arnedo-Pena A, Cordero-Cutillas E, CanósCabedo M, Herrero-Carot C, Safont-Adsuara L. The protective effect of alcoholic beverages on the occurrence of a Salmonella food-borne outbreak. Epidemiology. 2002;13(2):228-30. https://doi.org/10.1097/00001648-200203000-00020 PMID: 11880766 
23. Correia AM, Gonçalves G, Gomes A, Oliveira B, Gonçalves J,

Miranda $M$, et al. The protective effect of alcoholic beverages

in a foodborne outbreak of Salmonella Enteritidis PT1 in

northern Portugal. Euro Surveill. 2003;7(13):2195.

24. Desenclos JA, Klontz KC, Wilder MH, Gunn RA. The protective effect of alcohol on the occurrence of epidemic oyster-borne hepatitis A. Epidemiology. 1992;3(4):371-4. https://doi. org/10.1097/00001648-199207000-00013 PMID: 1637901

25. Romeo J, Wärnberg J, Nova E, Díaz LE, Gómez-Martinez S, Marcos A. Moderate alcohol consumption and the immune system: a review. Br J Nutr. 2007;98(S1) Suppl 1;S111-5. https://doi.org/10.1017/So007114507838049 PMID: 17922947

26. World Health Organization (WHO). WHO guidelines on Hand Hygiene in Health Care: First Global Patient Safety Challenge Clean Care is Safer Care. Geneva: WHO; 2009. Available from: https://www.ncbi.nlm.nih.gov/books/NBK144004/

27. Boerma T, Hosseinpoor AR, Verdes E, Chatterji S. A global assessment of the gender gap in self-reported health with survey data from 59 countries. BMC Public Health. 2016;16(1):675. https://doi.org/10.1186/s12889-016-3352-y PMID: 27475755

\section{License, supplementary material and copyright}

This is an open-access article distributed under the terms of the Creative Commons Attribution (CC BY 4.0) Licence. You may share and adapt the material, but must give appropriate credit to the source, provide a link to the licence and indicate if changes were made.

Any supplementary material referenced in the article can be found in the online version.

This article is copyright of the authors or their affiliated institutions, 2019. 